\title{
Sycamore Lace Bug, Corythucha ciliata (Say) (Insecta: Hemiptera: Tingidae) ${ }^{1}$
}

\section{Susan E. Halbert and James R. Meeker² \\ Introduction}

The sycamore lace bug, Corythucha ciliata (Say) is a native North American insect that feeds on sycamore trees (Platanus spp., especially Platanus occidentalis L.). The bugs feed on the undersides of the leaves, initially causing a white stippling that can eventually progress into chlorotic or bronzed foliage and premature senescence of leaves. In cases of severe infestations, trees may be defoliated in late summer. Several consecutive years of severe lace bug damage, combined with other stress factors, may kill the trees (Barnard and Dixon 1983). Heavy infestations are more common in urban areas than in natural settings. Damage is more severe during dry weather (Filer et al. 1977). The sycamore lace bug occurs throughout the eastern USA and in eastern Canada. In most years, it is common in most of the places that sycamores grow in Florida.

The sycamore lace bug was discovered in Europe in 1964 in Padova, Italy. Since that time, it has spread through much of southern and central Europe (d'Aguilar et al. 1977). In northern Italy, the sycamore lace bug is associated with two fungi,

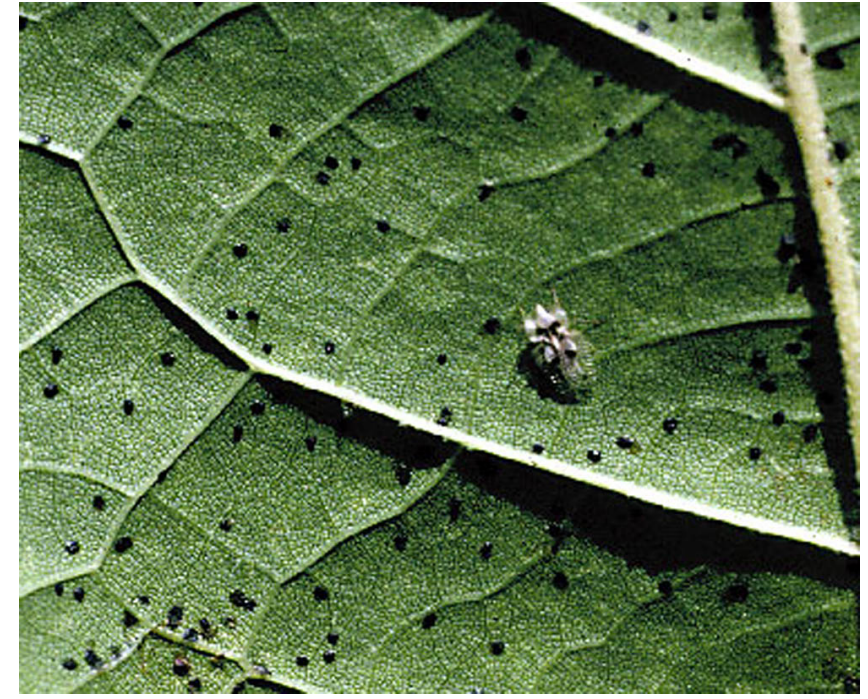

Figure 1. Adult sycamore lace bug, Corythucha ciliata (Say). Credits: Wayne Dixon, Division of Plant Industry

Ceratocystis fimbriata Ellis and Halst. forma platani J.M. Walter and Apiognomonia (=Gnomonia) veneta (Sacc. and Speg.), which, in combination with the lace bug, cause decline and death of the trees. It is suspected that the lace bugs may serve as vectors for these fungi (Maceljski 1986).

1. This document is EENY-190 (originally published as DPI Entomology Circular 387), one of a series of Featured Creatures from the Entomology and Nematology Department, Florida Cooperative Extension Service, Institute of Food and Agricultural Sciences, University of Florida. Published: February 2001. This document is also available on Featured Creatures Website at http://creatures.ifas.ufl.edu. Please visit the EDIS Website at http://edis.ifas.ufl.edu.

2. Susan E. Halbert, Florida Department of Agriculture and Consumer Services, Division of Plant Industry and James R. Meeker, Florida Department of Agriculture and Consumer Services, Division of Forestry.

The Institute of Food and Agricultural Sciences (IFAS) is an Equal Employment Opportunity - Affirmative Action Employer authorized to provide research, educational information and other services only to individuals and institutions that function without regard to race, creed, color, religion, age, disability, sex, sexual orientation, marital status, national origin, political opinions or affiliations. For information on obtaining other extension publications, contact your county Cooperative Extension Service office. Florida Cooperative Extension Service / Institute of Food and Agricultural Sciences / University of Florida / Larry R. Arrington, Interim Dean 
In addition to damaging trees, the sycamore lace bug has become a major nuisance in Europe, as sycamore is a very popular shade tree in parks in southern Europe. The sycamore lace bugs are particularly bothersome in open air bars and cafes that are shaded by sycamore trees. They also may invade homes in large numbers (Maceljski 1986).

\section{Description}

The sycamore lace bug is the only lace bug listed as feeding on $P$. occidentalis according to the world host list for lace bugs (Drake and Ruhoff 1965). Adults are whitish in color and about $3 \mathrm{~mm}$ in length. For practical purposes, the association with the host plant should be diagnostic for this species.

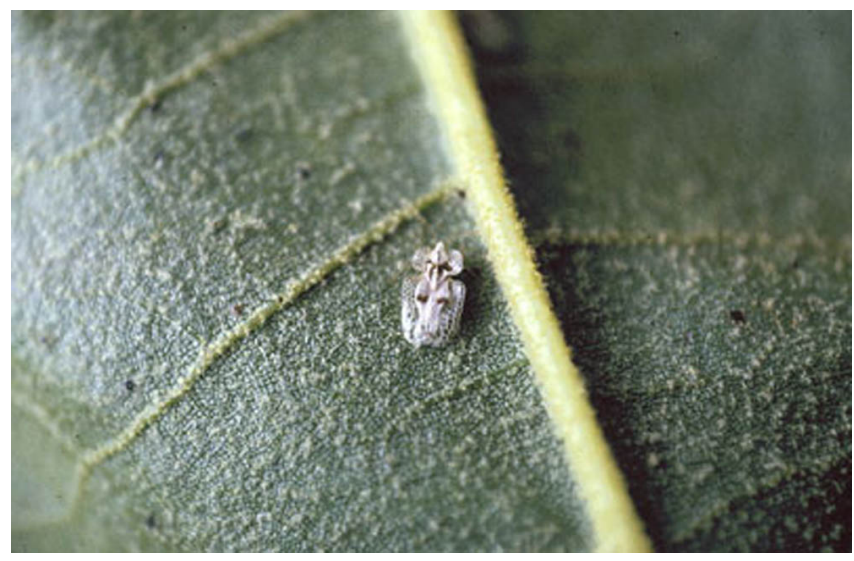

Figure 2. Closeup of adult sycamore lace bug, Corythucha ciliata (Say). Credits: Charles Chellman, Division of Forestry

Sycamore lace bug is very similar in appearance to Corythucha floridana Heidemann, the Florida oak lace bug, and to Corythucha gossypii (Fabricius), the cotton lace bug. The sycamore lace bug can be differentiated from other common Florida species by the following characters: the cells on the swollen part of the hood are slightly larger than those on the paranotal (lateral) area. The hood is only slightly higher than the median carina in lateral view. There is a brown spot at the rear of the tumid elevation in each eletron and there may be darkened veins near the posterior ends of the elytra. The following key separating common Florida species is taken from DPI Entomology Circular No. 324 on the cotton lace bug (Mead 1989). The entire genus was reviewed by Gibson (1918). Blatchley (1926) includes a key to eastern species.

\section{Key to Some Similar Appearing Species of Corythucha in Florida}

Taken from DPI Entomology Circular 324 on the cotton lace bug (Mead 1989).

1. Elytra usually with conspicuous brown basal and apical crossbars, but sometimes vague; hood larger, height 1.5-2.0+ times that of median carina. . .. 4

1'. Elytra with costal area not having conspicuous brown basal and apical crossbars; hood smaller, usually same height as median carina, sometimes slightly larger .... 2

2. Cells of globose portions of hood larger than those of paranota; median carina without well-defined, parallel-sided brown crescent mark .... 3

2'. Cells of globose portion of hood not larger than those of paranota; median carina with well-defined, parallel-sided brown crescent band. . . . . cotton lace bug, Corythucha gossypii (Fabricius)

3. Smaller, length $2.3-2.6 \mathrm{~mm}$; hood slightly but distinctly higher than median carina; color dingy white, a brown spot at rear margin of tumid elevation of each elytron, but also with vague brownish basal and apical markings on elytra. .... . Florida oak lace bug, Corythucha floridana Heidemann

3'. Larger, length 3.2-3.7 mm; hood approximately same height as median carina; color milky white, normally the only brown marking at rear of tumid elevation of each elytron. .... sycamore lace bug, Corythucha ciliata (Say)

4. Costal margins of elytra distinctly concave; hood height at least $2 \mathrm{X}$ height of median carina. .... . Morrill's lace bug, Corythucha morrilli Osborn \& Drake

4'. Costal margins of elytra nearly straight; hood height about 1.4-1.7 times height of median carina. . . . chrysanthemum lace bug, Corythucha marmorata Uhler 


\section{Life History}

The sycamore lace bug feeds on the undersides of leaves, causing dessication of tissue, first near the veins, and subsequently affecting the entire leaf, which may drop prematurely. The most detailed life history information on sycamore lace bug can be found in Wade (1917). According to Wade's (1917) observations in Oklahoma, mating pairs of sycamore lace bugs initiate colonies by laying eggs along leaf veins, especially near the forks. One to several pairs occupy a newly colonized leaf. A single female can lay at least 284 eggs. d'Aguilar et al. (1977) counted 350 eggs from one female. Wade (1917) observed five immature instars. Nymphs stay close together at first, only moving to new leaves after they reach the fourth instar. One life cycle is completed in 43 to 45 days under summer conditions in Oklahoma, and several generations per year occur in the South. Sycamore lace bugs overwinter as adults, either under loose bark of the trees, or in nearby cracks and crevices. They are extremely cold tolerant, withstanding temperatures as low as $-10^{\circ} \mathrm{F}$.

According to Wade (1917), the flying wings of adults are very delicate, and thus, these insects rarely fly very far; however, Maceljski (1986) writes that adults "are very mobile and are good fliers. Supported by wind they can fly over many kilometres." Both authors surmise that the majority of long distance distribution occurs as a result of human activity.

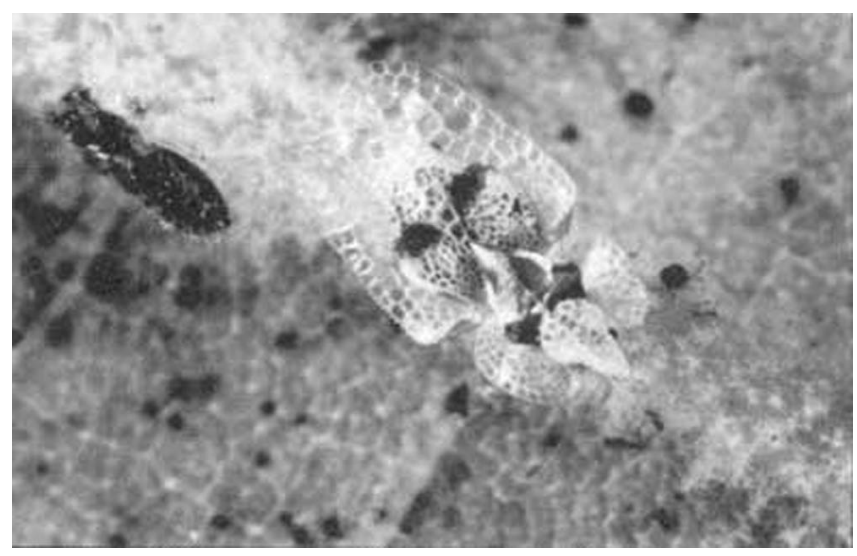

Figure 3. Nymph (upper right) and adult (center) of the sycamore lace bug, Corythucha ciliata (Say). Credits: Division of Plant Industry

\section{Hosts}

The major host of the sycamore lace bug is the American sycamore tree, $P$. occidentalis. Other Platanus spp. also may be affected (Wade 1917). Several other host plants are listed in the literature, including Broussonetia papyrifera (L.) Vent., Carya ovata (Mill.) K. Koch, Chamaedaphne sp., and Fraxinus sp. (Drake and Ruhoff 1965). The vast majority of Florida Department of Agriculture and Consumer Services, Division of Plant Industry (DPI) records for sycamore lace bugs list $P$. occidentalis as the host. There are no DPI host records for sycamore lace bug on Broussonetia, Carya, Chamaedaphne, or Fraxinus; however, there is one collection of a colony, including immatures, from Quercus laurifolia Michx. A single collection of both adults and nymphs from Liquidambar sytraciflua L. also contained sycamore lace bug. Single DPI records of sycamore lace bugs from Euphorbia pulcherrima Willd. ex Klotzsch, Castanea sp. and Vaccinium sp. could not be verified.

\section{Management}

There are several North American parasites and pathogenic fungi that attack sycamore lace bugs, but these seldom reduce populations enough to prevent significant damage to sycamore trees in Florida's urban areas. Although a wide variety of insecticides and associated methods of application (e.g., foliar sprays, trunk injections, soil treatments) are available for use against sycamore lace bugs, these are costly, and efficacy is often marginal. Additionally, there are problems associated with large scale use of insecticides in urban areas. Most of the time in Florida, applications of pesticides on sycamores are unnecessary and unwarranted. Despite the spectacular appearance of severe damage, the practical impact of occasional late- season defoliation on otherwise healthy sycamore trees is principally only aesthetic in nature.

\section{Selected References}

Barnard, E.L., and W.N. Dixon. 1983. Insects and diseases: Important problems of Florida's forest and shade tree resources. Florida Department of Agriculture and Consumer Services, Gainesville, FL. Bulletin No. 196-A. 120 p. 
Blatchley, W.S. 1926. Heteroptera or true bugs of eastern North America, with especial reference to faunas of Indiana and Florida. The Nature Publishing Company, Indianapolis. 1116 p.

d'Aguilar, R. Pralavorio, J.M. Rabasse, and R. Mouton. 1977. Introduction en France du tigre du platane: Corythucha ciliata (Say) (Het. Tingidae). Bulletin de la Société Entomologique de France 82: $1-6$.

Drake, C.J., and F.A. Ruhoff. 1965. Lacebugs of the world: A catalog (Hemiptera: Tingidae). Smithsonian Institution, Washington, D.C. United States National Museum Bulletin 213. 634 p.

Filer, T.H., J.D. Solomon, F.I. McCracken, F.L. Oliveria, R. Lewis Jr., M.J. Weiss, and T.J. Rogers. 1977. Sycamore pests: A guide to major insects, diseases, and air pollution. USDA Forest Service, Atlanta, GA. 36 p.

Gibson, E.H. 1918. The genus Corythucha Stål (Tingidae; Heteroptera). Transactions of the American Entomological Society 44 (775): 69-104.

Maceljski, M. 1986. Current status of Corythuca [sic] ciliata in Europe. Bulletin OEPP/EPPO Bulletin 16: 621-624.

Mead, F.W. 1989. Cotton lace bug, Corythucha gossypii, in Florida (Hemiptera: Tingidae). Florida Department of Agriculture and Consumer Services, Division of Plant Industry, Gainesville, Entomology Circular No. 324. 4 p.

Short, D.E., R.F. Mizell, and T.R. Fasulo. (1998). Woodybug: A knowledgebase of pest and beneficial arthropods of Florida woody ornamentals. UF/IFAS. CD-ROM

(http://pests.ifas.ufl.edu/software/det_woody.htm).

Wade, O. 1917. The sycamore lace-bug (Corythucha ciliata, Say). Oklahoma Agricultural Experiment Station Bulletin No. 116. 16 p. 